\title{
ULOGA INTERPRETACIJE U PROMOCIJI ARHEOLOŠKOG NASLEĐA SRBIJE
}

\section{Bojana Plemić, Branislav Rabotić}

Visoka turistička škola strukovnih studija, Beograd, Srbija

\section{Rezime:}

Atrakcije kulturno-istorijskog nasleđa, kao što su arheološki lokaliteti, srednjovekovni manastiri i utvrđeni gradovi, artiljerijske fortifikacije i sl., predstavljaju važan segment turističke ponude Srbije. Kada se radi o arheološkim ostacima, izuzev nekoliko lokaliteta iz doba praistorije, poput Lepenskog vira, Vinče ili Drenovca, najveći potencijal za turizam u Srbiji predstavlja baština iz perioda rimske dominacije. Povezivanjem lokaliteta kao što su Sirmijum, Viminacijum, Trajanova tabla i Trajanov most, Šarkamen, Naisus i Medijana, Caričin grad, Dijana Karataš, Kale Krševica, Hisar i Drenovac osmišljena je kulturna ruta (Put rimskih careva) koja vodi putnika kroz vreme kada je Dunav bio istočna granica Rimske imperije. Autori se u ovom radu osvrću na neka pitanja prezentacije i interpretacije srpskih arheoloških lokaliteta u turizmu, naglašavajući značaj pre svega tzv. neposredne interpretacije za doživljaj posetilaca i turista. Treba imati u vidu da arheološka nalazišta ne posećuju samo (masovni) turisti koji su tek usputno zainteresovani za razgledanje, već i oni koji zbog tih atrakcija ciljano biraju destinaciju svog putovanja. U tom slučaju radi se o arheološkom turizmu ili tzv. arheoturizmu, kao specifičnom obliku kulturnog turizma, koji zahteva i odgovarajuću raznovrsnost kvalitetne interpretacije na licu mesta.

Ključne reči:

arheološki lokalitet, turizam, prezentacija, interpretacija, rimska baština

Interpretacija vodi, omogućava i ohrabruje. Interpretacija obrazuje. Interpretacija zabavlja. Interpretacija izlaže. Interpretacija informiše.

Ali, pre svega, interpretatori obogaćuju turistički doživljaj suštinom $i$ osećanjem lične ispunjenosti.

(Knudson et al., 2003, p.12)

UVOD

Činjenica je da su današnji turizam, sa jedne strane, i arheologija - kao "naučno proučavanje nekadašnjih kultura, kako preistorijskih tako i istorijskih" - s druge strane, povezani iako "turizam per se nije tradicionalno u fokusu akademskog istraživačkog rada" (Kamp, u: Jafari, 2000, p.28). Ova veza se, uglavnom, ispoljava kroz pitanje dostupnosti arheološkog nasleđa za turističku posetu, turističke valorizacije
Correspondence:

Bojana Plemić

e-mail:

bojana.plemic@visokaturisticka.edu.rs 
i prezentacije, osetljivosti arheološkog materijala i štetnog uticaja posetilaca na pojedine objekte i artefakte, potrebe za dodatnom arheološkom zaštitom u uslovima regularne i vanredne eksploatacije i sl. Kod turističke eksploatacije arheološkog nasleđa posebno dolazi do izražaja neophodnost obezbeđenja održivosti koja mora uvažavati, kako to naglašava Moscardo (2003) tri bitne komponente - kvalitet, kontinuitet i ravnotežu.

Brojni arheološki lokaliteti širom sveta danas funkcionišu kao istaknute i vrlo posećene turističke atrakcije, pri čemu se neke od njih nalaze i na prestižnoj listi spomenika zaštićene svetske baštine (World Heritage Sites). U pojedinim zemljama, poput Meksika, Grčke ili Italije, arheološki lokaliteti su ne samo važan i atraktivan segment ponude u tamošnjem receptivnom, masovnom turizmu, već i "ikonične atrakcije" ili "kulturne ikone" (Holloway, 2006, p.217) toliko slavne da su njihov imidž i destinacija nerazdvojni u svesti turista (atinski Akropolj, Koloseum, Čičen Ica i sl.). Zato se arheološka mesta i simboli često koriste u promociji od strane nacionalnih turističkih organizacija.

Danas se sve više govori o posebnom obliku turizma, arheološkom ili arheoturizmu, koji je usmeren na posetu turista arheološkim mestima i objektima, kao i na aktivnosti od arheološkog značaja (Giraudo; Mortensen, u: Jafari i Xiao, 2016). Kao vrsta selektivnog, preciznije rečeno kulturnog turizma, arheoturizam nije zanemarljiva niša na međunarodnom turističkom tržištu, zbog čega postoje i specijalizovani turoperatori koji priređuju organizovana putovanja sa intenzivnim programom arheološkog sadržaja, kao što je nemački Studiosus. Pomenuti autori čak smatraju da ovaj vid turizma ima dosta sličnosti ne samo sa turizmom baštine i kulturnim turizmom, već i sa naučnim (edukativnim) turizmom, budući da on uključuje i posete sa ciljem istraživačkog rada u oblasti arheologije.

Walker i Carr (2013) uočavaju da arheološki turizam nije nešto novo, ali je u prošlosti funkcionisao kao "rezervat" manjine, dok danas odražava enormni rast turizma u celini. Autori ističu da su tradicionalni posetioci arheoloških lokaliteta bili pripadnici obrazovane manjine, nalik na arheologe ili istoričare, zadovoljni posetom nalazištima bez vizitorskih centara, ugostiteljskih sadržaja i suvenirnica, bez ili sa vrlo malo informacija dostupnih na licu mesta. Takvi posetioci još uvek postoje, ali prosečan turista često je zainteresovan za trgovačku ili ugostiteljsku ponudu na lokalitetu koliko i za arheološke iskopine odnosno izložene artefakte. Osim edukacije, autentičnosti doživljaja ili potrebe za pružanjem podrške naporima u zaštiti nasleđa, takvom posetiocu i zabava predstavlja značajan razlog za posetu kulturno-istorijskom mestu.

\section{ARHEOLOŠKE ATRAKCIJE SRBIJE}

Što se Srbije tiče, arheološki turizam je tek u začetku. Takvu situaciju, uprkos izuzetno bogatom i značajnom nasleđu koje zemlja poseduje, uslovljavaju različiti problemi počev od nedostatka nacionalne strategije u pogledu mera zaštite i prezentacije, pa sve do lošeg vrednovanja sopstvene baštine od strane lokalnih zajednica. U poslednjoj deceniji pak, može se reći da se situacija menja u pozitivnom pravcu zahvaljujući pojedinačnim naporima istraživača, kao i uključivanju srpskih lokaliteta u međunarodne projekte poput Putevima rimskih careva i Dunavski put vina, Danube Limes brand, Archest i sličnih, koji se, između ostalog, bave turističkom promocijom i edukacijom posetilaca uz primenu modernih načina interpretacije kulturnog nasleđa (Plemić, 2017).

Izuzev nekoliko lokaliteta iz doba praistorije, poput Lepenskog vira, Vinče ili Drenovca, najveći potencijal arheološkog turizma u Srbiji predstavlja baština iz perioda rimske dominacije. Upravo je ona prepoznata kao integralna ruta još 1996. godine kada je iniciran projekat Putevima rimskih careva (Itinerarium Romanum Serbiae) sa idejom da se unapredi i modernizuje infrastruktura vezana za lokalitete na putevima rimskih imperatora u Srbiji, spajajući sve naučno-kulturne projekte na tu temu i prepoznajući ih kao odličnu šansu za razvoj turizma. Povezivanje lokaliteta kao što su Sirmijum, Viminacijum, Trajanova tabla i Trajanov most, Šarkamen, Naisus i Medijana, Caričin grad, Dijana Karataš, Kale Krševica, Hisar i Drenovac, uz delimično obnavljanje antičkog puta, u kulturnu rutu od regionalnog značaja, trebalo je da obezbedi prosperitet i održivost ovih nalazišta kroz povećanje godišnjeg broja posetilaca (Korać, 2013).

Uprkos tome što i danas, nakon više od dve decenije od inicijalne zamisli, pomenuti projekat nije zaživeo u svom originalnom vidu, odnosno nije postigao projektovanu posetu od oko 300 hiljada posetilaca na godišnjem nivou (Korać, 2013, p.11), većina obuhvaćenih lokaliteta dosta je napredovala po pitanjima prezentacije 
odnosno pripreme za turističku posetu. Shodno tome, 2015. godine je sertifikovana kulturna ruta od strane Saveta Evrope pod nazivom Putevima rimskih imperatora i Dunavski put vina, koja je obuhvatila 20 rimskih gradova i 12 vinskih regija u Bugarskoj, Rumuniji, Hrvatskoj i Srbiji, kao dodatan podstrek promociji ovih predela u evropskom turizmu. ${ }^{1} \mathrm{Na}$ ovoj ruti našlo se pet srpskih lokaliteta: Sirmijum, Viminacijum, Feliks Romulijana (Gamzigrad), utvrđenje Dijana Karataš i Medijana. Izuzev utvrđenja Dijana, koje je samo konzervirano i ne tako atraktivno (ali zbog svoje pozicije vrlo pogodno za posetu prilikom obilaska drugih lokaliteta u okolini), za ostala nalazišta koja su prethodno pomenuta, može se reći da su u protekloj deceniji najviše napredovala kada se radi o procesu ne samo integrativne zaštite, već i prezentacije kao preduslova za aktivno korišćenje u turizmu.

\section{ULOGA I ZNAČAJ INTERPRETACIJE}

Interpretacija kao pojam ima više značenja, ali u kontekstu ovog rada najprihvatljivije daje Encyclopedia of Tourism: "bilo koja aktivnost koja ljudima objašnjava značaj nekog objekta, kulture ili mesta" (Jafari, 2000, p.327). ${ }^{2} \mathrm{U}$ pogledu arheološkog turizma interpretacija se nameće kao važna komunikativna veza između turizma i nasleđa, kojom se posetiocima objašnjava smisao i vrednost konkretnih objekata baštine, koji po pravilu nisu vizuelno impresivni (ostaci u vidu iskopina temelja, donjih delova zidova, baza stubova itd.) jer "turistima ne znače mnogo ostaci na nekom arheološkom nalazištu ili fasada stare zgrade ukoliko ne čuje priču o njima, ukoliko se likovi i događaji povezani sa tim mestom ne ožive pred očima posetilaca" (Đukić Dojčinović, 2005, p.52). Još preciznije, interpretacija je oblik komunikacije između odgovornih za upravljanje destinacijom ili atrakcijom i onih koji je posećuju (Moscardo; u: Jafari, 2016). Stoga uspešna interpretacija predstavlja ključ za efektivnu valorizaciju lokaliteta u turizmu kao "obrazovna aktivnost čiji je cilj više usmeren na otkrivanje značenja i odnosa... posredstvom doživljaja iz prve ruke i ilustrativnih sredstava, a manje običnim faktografskim nabrajanjem podataka..." (Tilden 1977, p.14).

Interpretacija se može ostvarivati direktno i indirektno. Indirektna podrazumeva komuniciranje posredstvom različitih medijskih sredstava kao što su plakati, brošure, planovi, audio ili audio-vizuelni vodiči, uređena staza sa oznakama, turistička signalizacija ili interaktivna tabla. Neposredna ili direktna interpretacija ostvaruje se interakcijom između tumača (vodič, kustos, informator, predavač) i posetilaca, tj. turista. Ovakvu vrstu interpretacije najpre su usvojili nacionalni parkovi i rezervati kroz koncept interpretacije prirode, početkom XX veka, zatim muzeji i slične javne institucije, da bi nakon toga zaživela i u komercijalnom turizmu. Načini direktne interpretacije nasleđa su raznovrsni, od klasičnih, na licu mesta, kroz tematska predavanja, razgledanja i šetnje sa vodičem, ili van atrakcije gde se putem novih tehnologija i sredstava posredne interpretacije ona vizuleno oživljava. Međutim, neki autori, polazeći od pretpostavke da svi ljudi imaju dovoljno znanja i sposobnosti da sami otkrivaju vrednost baštine, smatraju kako interpretacija, zapravo, onemogućava neposredni doživljaj (Timothy i Boyd, 2003), dok se kritika interpretacije može odnositi i na način kako se ona sprovodi u praksi jer se neretko koristi za političku propagandu ili manipulaciju (Rabotić, 2013). ${ }^{3}$

Budući da je kulturna osetljivost vrlo važan princip kada se radi o upravljanju baštinom, kao jedan od glavnih problema u neposrednoj interpretaciji nameće se nužnost objektivnog pristupa i neutralnosti, kao i prilagođenosti auditorijumu. Jednoj grupi posetilaca nije uvek interesantno tumačenje koje odgovara drugoj, različitoj po starosnoj strukturi, obrazovanju, socijalnom poreklu, nacionalnoj pripadnosti i slično. Stoga u postmodernom vremenu dobar interpretator mora ponuditi ono što se ne može dobiti posredstvom bilo kog drugog medijuma, proširujući svoju tradicionalno nametnutu ulogu koja se odnosi na obezbeđivanje pristupa određenom prostoru, na intelektualni teren koji bi inače ostao nedostupan (McGrath, 2003).

1 Dunavski centar za kompetenciju, 2014 (http://danubecc.org/dcc-projects/the- -roman-emperors-and-danube-wine-route/ (pristup: 10.09.2018); romanemperorsroute.org/bloggers- -trip-along-transromanica-and-roman-emperors-and-danube-wine-route/ ( pristup: 10.09.2018).

2 Ovo tumačenje je u vezi sa originalnim značenjem latinskog pojma interpretatio koje se odnosi na aktivnost prenosilaca i tumača poruka i znakova posebno u mitološkom kontekstu gde je recimo Hermes tumačio poruke bogova ljudima.

3 Jedan od oblika neposredne interpretacije, posebno popularan u SAD, jeste koncept living history odnosno living heritage, kada se obučeno osoblje, najčešće kustosi u odgovarajućim kostimima, obraća posetiocima kao istorijska ličnost koja "rekonstruiše" prošlost. Ipak, prema nekim mišljenjima takav koncept iako vizuelno interesantan, budeći osećanje za prošlost kod posetilaca, nema zadovoljavajući edukativni karakter (Reisinger and Steiner, 2006). To je verovatno jedan od osnovnih razloga što se u prezentaciji sprskih nalazišta ovaj koncept još uvek primenjuje samo sporadično, prilikom nastupa na sajmovima turizma ili nekih posebnih događaja i zvaničnih poseta. 
Danas se interpretacija sve više sagledava u kontekstu očuvanja nasleđa, gde je njen primarni cilj da ohrabri pojedince i zajednice na uspostavljanje značajne veze sa baštinom, kako bi je, kroz sticanje novih znanja, koristili na različite načine. ${ }^{4} \mathrm{Na}$ taj način interpretacija, za razliku od standardne prezentacije arheoloških artefakata, otkriva značenja iz materijalnih i nematerijalnih ostataka prošlosti i arheološke objekte razvija kao izvore zajedništva, znanja, zabave i zarade (Živanović, 2014).

Međutim, sami arheolozi interpretaciju vezuju za pitanja konteksta, ali i za objektivnost istraživača i njegovu društvenu i političku uslovljenost, dok se neminovno nameće i pitanje autoriteta u arheologiji koje otvara dilemu od čega ili koga zavisi čije je mišljenje u arheologiji merodavnije (Ćosić, 2016). "Danas dva nova pravca, arheologija za javnost i arheologija zajednice, pokušavaju da doprinesu rešenju ovog problema, odnosno da izbalansiraju odnos između arheologije, nasleđa i različitih zajednica koje utiču na njegovo stvaranje, čuvanje i korišćenje. Tako arheologija za javnost teži povećanju transparentnosti i široj vidljivosti rezultata istraživanja i značaja arheologije, dok se arheologija zajednice zasniva na razvijanju kompleksne komunikacije, interakcije i saradnje sa zajednicom, koja za cilj ima održivi razvoj" (Živanović, 2014, p. 31). ${ }^{5}$

Sa druge strane, brojni autori zagovaraju interpretaciju kao disciplinu, posmatrajući je isključivo kao obrazovni ili komunikacijski proces vezan za prezentaciju i promociju nasleđa. Stoga se nameće uloga vodiča odnosno tumača i stručnjaka za interpretaciju kao važnog komunikatora, ne samo između nasleđa i publike, već i različitih stavova arheologije i zagovornika intrpretacije kao posebne discipline. On nužno mora posedovati svestrano znanje o samom lokalitetu i njegovoj okolini, uz mogućnost alternacija više tema koje će prilagođavati određenim grupama posetilaca. Iako je svako arheološko nalazište jedinstveno, nudeći neponovljivo iskustvo, "za svako od njih se mogu vezati i univerzalne teme koje stavljaju posetioca u centar dešavanja i olakšavaju mu da prihvati svoju obavezu prema zaštiti životne sredine, da razume način na koji se dolazi do potvrde, ili odbacivanja određene naučne hipoteze, da prihvati činjenicu da nasleđe ima različit značaj za različite ljude" (Živanović, 2014, p.159).

Takođe, potrebno je uvek imati u vidu da interpretacija nije namenjena stručnoj, pa ni dobro informisanoj publici. Zato je od krucijalnog značaja i sposobnost interpretatora da svoja znanja prenese drugima, što znači da kada priređuje turu po lokalitetu mora vladati i tehnikom vođenja, uključujući pravilnu navigaciju posetilaca, njihovo pozicioniranje na bitnim mestima, tajming u komentarisanju, projekciju glasa, neverbalnu komunikaciju, preciznost u pokazivanju i slično (Rabotić, 2010).

\section{NEKI ASPEKTI PREZENTACIJE ARHEOLOŠKIH LOKALITETA SRBIJE}

U procesu modernizacije načina prezentacije lokaliteta od presudnog značaja je upotreba novih tehnologija koje na vizuelno prijemčiv način oživljavaju ostatke prošlosti. Tako je Feliks Romulijana (Gamzigrad), kao jedino rimsko nalazište u Srbiji upisano na UNESCO listu svetske baštine, tokom 2015. godine dobilo android aplikaciju za mobilne telefone i tablete koja prati svetski muzeološki trend sa namerom da se ostvari što bolja

4 Jedan od dobrih primera uspešne neposredne interpretacije kulturnog nasleđa namenjene lokalnom stanovništvu bio je projekat "Razgledanje Beogradske tvrđave" pokrenut 1998. godine. Reč je o prvom primeru organizovane, masovne i besplatne interpretacije spomeničke baštine u Srbiji u obliku vođene ture koju je tokom trajanja projekta u periodu 1998-2008.godine posetilo oko 30.000 Beograđana (Rabotić, 2010, p. 176). Početna ideja o "turističkim obilascima", u pratnji vodiča, ubrzo je spontano prerasla u vođene nterpretativne ture, čiji su koncept, principi i način realizacije usklađeni sa preporukama Povelje za interpretaciju i prezentaciju lokaliteta kulturnog nasleđa. Međutim, iako su različiti mediji pratili i više puta izveštavali o izvođenju ovih tura, što kroz novinske članke, što kroz televizijske priloge, vrednost ovog projekta nije shvaćena na pravi način jer je potpuno zanemarena njegov edukativna uloga. Tome u prilog govori i činjenica da uprkos preporuci Ministarstva prosvete, nijedna beogradska škola nije uputila svoje đake da kroz ovu zanimljivu šetnju saznaju više o prošlosti svoga grada. Međutim, pozitivni efekti ovakvog načina interpretacije spomeničkog nasleđa bili su vidljivi nešto kasnije, kada su shodno iskustvu ovih i sličnih tura, pokrenute manifestacije poput "Dani evropske kulturne baštine" i "Međunarodni dan turističkih vodiča", koje su ukazale na veliko interesovanje građana za upoznavanje sopstvene kulturne baštine (ibid.).

5 Douglas (2012, p.11) na slikovit način ističe: "Arheološki lokaliteti razlikuju se od mesta zločina, sa kojima ih, ponekad porede, i to u vrlo bitnom aspektu: za razliku od policije koja ne poziva hiljade ljudi da dođu na mesto koje je pod istragom, rukovodioci arheoloških lokaliteta upravo to rade. U proteklih nekoliko decenija, arheolozi i drugi stručnjaci, poput istoričara umetnosti, konzervatora, geografa, geomorfologa ili kartografa, spoznali su da moraju neposrednije angažovati javnost nego što to čine samo pisanjem elaborata. Iz tog razloga, prihvatili su arheologiju za javnost koja, često, podrazumeva posetu arheološkom lokalitetu. To rade, delom, i kao vid unošenja transparentnosti u arheološka istraživanja”. 
interakcija posetilaca sa predstavljenim sadržajima. ${ }^{6}$ Takođe, tokom 2016. godine ovde je dovršeno opremanje savremenog multimedijalnog centra za posetioce kao prostora gde se oni mogu upoznati sa izgledom Feliks Romulijane u vreme njenog procvata koristeći 3D naočare i holograme. Pokretima ruke pred ekranom može se "šetati" po idealnoj rekonstrukciji carskog kompleksa, dok su im na raspolaganju i trodimenzionalne animacije (tzv. proširena realnost) na interaktivnim panelima, kao i originalni artefakti putem kojih se dočarava autentični ambijent. Ovakva primena modernih tehnoloških dostignuća kao glavni cilj ima da na popularan i atraktivan način približi istoriju odnosno kulturno nasleđe široj populaciji, razbijajući predrasude o arheologiji kao nauci namenjenoj samo obrazovanim stručnjacima, što se, iako je reč o skorašnjim implementacijama, već pozitivno odrazilo na porast broja posetilaca, kako domaćih tako i stranih (Plemić, 2018).

Pored Feliks Romulijane, značajan napredak zapaža se i na drugim lokalitetima poput Sirmijuma koji duži niz godina učestvuje u međunarodnom projektu Archest. ${ }^{7}$ Njegov osnovni cilj je edukacija posetilaca arheoloških lokaliteta duž rimskog puta Akvileja-Emona-Sirmijum-Viminacijum, odnosno njihova turistička promocija kroz uvođenje tehnologije proširene stvarnosti kako bi se posetiocima što plastičnije dočarao izgled naselja u antičko vreme. Tako je tokom 2017. godine urađena 3D rekonstrukcija carske palate Sirmijuma koja se danas može videti putem interaktivnih monitora na samom lokalitetu, vizuelno dočaravajući atmosferu ovog raskošnog zdanja, dok rezultati u poboljšanju turističke posete polako postaju vidljivi (Plemić, 2018).

Ipak, najboljom turističkom prezentacijom može se pohvaliti Viminacijum, koji je ujedno i prvi arheološki park u Srbiji osnovan 2006. godine. Nekadašnji legijski logor i rimski grad, prestonica provincije Gornje Mezije, danas poseduje sedam pokrivenih objekata otvorenih za posetioce: glavnu kapiju legijskog logora (Porta praetoria), terme, amfiteatar, mauzolej u kojem je najverovatnije sahranjen rimski imperator Hostilijan, mamut park, Domvs Scientiarvm Viminacium - rekonstruisanu villa rustica koja funkcioniše kao naučno istraživački i turistički centar, kao i zanatski centar sa pećima za proizvodnju keramike i opeke. U sklopu pomenutog projekta Archest, trenutno se radi na virtuelnoj rekonstrukciji Viminacijuma, kao tehnološkoj inovaciji koja će dodatno unaprediti već solidnu ponudu lokaliteta koji prednjači u odnosu na ostale po godišnjem broju posetilaca od 80.000 do 100.000 (Mrđić, 2012; Paardekooper, 2014). Koncept po kome se Viminacijum takođe izdvaja, jeste i ponuda smeštajnih kapaciteta koji podrazumevaju hotelske sobe u autentičnom rimskom stilu, uz mogućnost da se uživa u originalnom obroku. Jedan od tek završenih projekata jeste i rekonstrukcija legionarskog parka većeg kapaciteta, trenutno namenjenog smeštaju naučnika okupljenih na svetskom kongresu arheologa Limes $2018,{ }^{8}$ koji će kasnije biti namenjen za boravak ekskurzija ili dece u edukativnim kampovima. Primenjujući i tzv. kulturu spektakla odnosno koncept living history, koja se odnosi na dočaravanje atmosfere prošlosti kroz kostimirane vodiče i osoblje, rekonstrukciju pojedinih običaja, igara i rituala davnih vremena, Viminacijum danas dominira u pokušaju stvaranja kvalitetnog doživljaja namenjenog turistima savremenog doba (Mrđić, 2012; Ognjević, 2013).

Pored navedenih Feliks Romulijane, Sirmijuma i Viminacijuma, ovom prilikom neophodno je napomenuti da se po pitanju prezentacije izvesni napori ulažu i na Medijani kod Niša. Na tom nalazištu je u poslednjim godinama izgrađena monumentalna zaštitna konstrukcija nad tzv. peristilom, odnosno dvorištem prekrivenim mozaicima, što je omogućilo da ih posetioci, po prvi put od kada su otkriveni, mogu videti u punom sjaju. Osim toga, postoje planovi daljih aktivnosti na turističkoj prezentaciji ovog lokaliteta. ${ }^{9}$

Kroz ovaj kratak pregled stanja u pogledu unapređenja najznačajnijih nalazišta rimske epohe u Srbiji za turističku posetu, može se videti da su najveća pažnja i ulaganja usmereni na posrednu ili indirektnu interpretaciju lokaliteta, gde se upotrebom novih tehnologija akcenat stavlja na vizuelni doživljaj i senzaciju. Postavlja se, međutim, pitanje koliko je takav pristup dovoljan da stimuliše trajniji utisak posetioca i obezbedi

6 Ovaj inovativni turistički proizvod zapravo predstavlja jednu vrstu igre koja je zamišljena po modelu potrage za blagom, gde posetilac dobija zadatak zarad čijeg rešenja se mora proštetati do naznačenog mesta uz pomoć legende muzejskih predmeta koje ga vode kroz istoriju lokaliteta. Tako posetilac na kratko postaje arheolog koji istražuje delove palate, učestvuje u religijskim ritualima rimskog doba, saznajući brojne detalje iz biografije cara Galerija, kao i podatke kako su Rimljani živeli i provodili svoje slobodne vreme. Ova aplikacija je za sada jedinstvena u Srbiji po tome što je zamenila tradicionalno vođenje igrom koja nudi nov pristup istoriji i arheološkoj baštini, stvarajući lično iskustvo koje se pamti, posebno među mlađim generacijama.

7 Zavod za zaštitu spomenika kulture Sremska Mitrovica, Projekti (http://zavodsm.rs/project/archest/?ltr=lat); Project ARCHEST (http://archest.eu/project/).

8 http://limes2018.org/travel-accommodation/limes-park-viminacium/ (pristup:11.09.2018.)

9 http://narodnimuzejnis.rs/za-posetioce/radno-vreme/ (pristup:11.09.2018.);

https://www.juznevesti.com/Kultura/Uskoro-potpuno-renoviranje-nalazista-Medijana-i-dela-sale-Lutkarskog.sr.html (pristup: 11.09.2018.) 
mu istinsko edukativno iskustvo? Neposrednu interpretaciju, u njenom suštinskom obliku, trebalo bi videti kao zanimljivu priču, koja različite istorijske, kulturne ili naučne pojmovnosti i pojedinosti saopštava jasnim govorom razumljivim običnom čoveku koji ne poseduje stručna znanja. Ona ima za cilj da kod posetioca izazove prijatne emocije i divljenje, kao i odnos poštovanja prema prirodnoj i kulturnoj sredini, zbog čega se njen izuzetan značaj ne bi smeo zanemariti. Uspešna interpretacija ne nameće, već samo sugeriše konkretne zaključke posetiocu, podstiče ga na razmišljanje i doživljaj kulturnog dobra kroz sasvim ličnu prizmu, što efikasnije doprinosi kvalitetu usvojenih znanja i iskustava. Sve to upućuje na potrebu da se, uporedo sa modernizacijom prezentacije lokaliteta u Srbiji, nužno poradi i na direktnoj interpretaciji kao bitnom promotivnom sredstvu u menadžmentu arheološkog turizma. Ovo je utoliko potrebnije što je većina arheoloških lokaliteta, premda nesumnjivo značajnih kao delova autentične kulturne baštine, po pravilu niskog nivoa očuvanosti, odnosno, za razliku od nekih drugih kulturnih atrakcija, ne tako impresivnog vizuelnog efekta.

\section{ZAKLJUČAK}

Srbija poseduje značajno arheološko nasleđe, ali njegova turistička valorizacija, prezentacija i eksploatacija još uvek nije ostvarena u potrebnoj meri. Imajući u vidu to da se, uglavnom, radi o nasleđu iz doba rimske dominacije, izuzetno je važna inicijalna zamisao projekta Putevima rimskih careva, iako do sada nije ostvarena planirana poseta ove rute od oko 300 hiljada posetilaca godišnje. Ipak, većina lokaliteta obuhvaćenih tim projektom dosta je napredovala po pitanju prezentacije i pripreme za turističku posetu. Najboljom turističkom prezentacijom može se pohvaliti Viminacijum, koji je ujedno i prvi arheološki park u Srbiji. Tamo se trenutno radi i na virtuelnoj rekonstrukciji kao tehnološkoj inovaciji koja će, nesumnjivo, dodatno unaprediti postojeću ponudu, dok se i na ostalim pomenutim lokalitetima uglavnom koriste sredstva posredne interpretacije, pojedinačna ili multimedijalna.

U radu je posebno istaknuto da interpretacija ima cilj da posetiocima i turistima objasni značaj lokaliteta, objekata i artefakata i doprinese razumevanju, pozitivnom utisku i divljenju, a time i povećanju svesti o potrebi za očuvanjem kulturno-istorijskog nasleđa. Zbog toga dostupnost, raznovrsnost i, pre svega, kvalitet interpretativnih medija imaju znatan uticaj ne samo na turističku valorizaciju arheoloških atrakcija već i na konkurentsku sposobnost destinacije gde se one nalaze. Shodno tome neophodno je staviti akcenat i na neposrednu interpretaciju, kod koje do izražaja dolazi pre svega ljudski faktor, postojanje obučenih interpretatora, kustosa i vodiča. Od njih se očekuje ne samo izvrsno poznavanje arheološkog lokaliteta i okolnog ambijenta, već i da poseduju dodatna znanja iz raznih oblasti. Istovremeno moraju vladati i određenim veštinama od kojih zavisi efikasnost prenošenja znanja i kvalitet doživljaja posetilaca. Najkraći i najsigurniji put ka ostvarenju takvog cilja bilo bi kreiranje posebnih programa obuke i, eventualno, sertifikacija "interpretatora kulturnog nasleđa”. U svakom slučaju, za uspešan razvoj arheoturizma neophodna je saradnja svih stejkholdera - kulturnih ustanova, državnih i paradržavnih turističkih organizacija, agencija za marketing destinacije, menadžmenta arheoloških atrakcija, obrazovnih institucija koje školuju kadrove za potrebe turizma, stručnih udruženja, turističkih agencija i drugih ponuđača usluga u ovoj vrsti turizma. 


\section{LITERATURA}

Grupa autora (2007). Master plan kulturno-istorijske rute Putevima rimskih careva. Beograd: Vlada republike Srbije i Ministarstvo ekonomije i regionalnog razvoja.

Ćosić, N. (2016). Autoritet i proizvodnja arheološkog znanja. Etnoantropološki problem, 11(3), 749-774. DOI: 10.21301/eap.v11i3.6

Douglas, C.C. (2012). Tourism and Archaeological Heritage Management at Petra: Driver to Development or Destruction? New York: Springer.

Đukić Dojčinović, V. (2005). Kulturni turizam. Beograd: Klio.

Holloway, J.C. (2006). The Business of Tourism. $7^{\text {th }}$ ed. Harlow: Pearson Education.

Jafari, J. (2000). Encyclopedia of Tourism. London: Routledge.

Jafari, J., \& Xiao, H. (2016). Encyclopedia of Tourism. London: Springer International Publishing.

Knudson, M.D., Cable, T.T., \& Beck, L. (2003). Interpretation of Cultural and Natural Resources. State College, PA: Venture Publishing.

Korać, M. (2013). Pre-feasibility Study Itinerarium Romanum Serbiae. Archaeology and Science, Vol. 9: 9-35.

McGrath, G. (2003). Myth, Magic, Meaning \& Memory: Mentor Tour Guides as Central to Developing Integrated Heritage Tourism at Archaeological Sites in Cusco, Peru. Guildford: University of Surrey.

Mrđić, N. (2012). Roman Cultural Heritage as a Tourist and Educational Resource. Archaeological Heritage: Methods of Education and Popularization (eds. R. Chowaniec and W. Więckowski), BAR International Series 2443: 121-127.

Ognjević, T. (2013). Archaeological heritage and modern spectacle as cultural entrepreneurship experiment. Archaeology and Science 9: 149-154.

Paardekooper, R. et al. (2014). Viminacium and the Openarch Project. Archaeology and Science 10: 211-220.

Plemić, B. (2017). Evropski projekti kulture i njihova uloga u turističkoj promociji domaće arheološke baštine. Turističko poslovanje 19: 5-13.

Plemić, B. (2018). New Technologies in Presentation of Serbian Archaeological Heritage: Impact on Tourism. Kokino: Giving Gifts to Gods, Evidences of Votive Offerings in the Sanctuaries, Temples and Churches, Conference Proceedings, National Museum of Kumanovo 2018: 225-236.

Rabotić, B. (2010). Interpretacija spomeničkog nasleđa: Razgledanje Beogradske tvđave. Singidunum revija, 6(2), 2010: 166-179.

Rabotić, B. (2013). Selektivni oblici turizma. Beograd: Visoka turistička škola strukovnih studija.

Reisinger, Y., \& Steiner, C. (2006). Reconceptualising Interpretation: The Role of Tour Guides in Authentic Tourism, Current Issues in Services, 9(6): 481-498.

Tilden, F. (1977). Interpreting our Heritage, $3^{\text {rd }}$ edn. Chapel Hill, NC: The University North Carolina Press.

Timothy, D.J., Boyd, S.W. (2003). Heritage Tourism. Harlow: Pearson.

Walker C., Carr, N. (2013). Tourism and Archaeology: An Introduction. In: Walker , C. Carr, N. (ed.) Tourism and Archaeology. Sustainable Meeting Grounds (11-36). Walnut Creek, CA: Left Coast Press.

Živanović, K. (2014). Interpretacija kulturnog nasleđa kao preduslov za korišćenje arheološke baštine u društvenoekonomskom razvoju zajednice. Neobjavljena doktorska disertacija. Univerzitetu u Beogradu: Filozofski fakultet. 


\title{
THE ROLE OF INTERPRETATION IN THE PROMOTION OF SERBIA'S ARCHAEOLOGICAL HERITAGE
}

\begin{abstract}
:
The most significant segment of Serbia's tourist offer are attractions of cultural and historical heritage such as archaeological sites, medieval monasteries and fortified cities, artillery fortifications, etc. When it comes to archaeological remains, except for several prehistoric sites, such as Lepenski Vir, Vinča or Drenovac, the heritage of Roman domination has the greatest potential for tourism in Serbia. By linking the sites such as Sirmium, Viminacium, a Roman memorial plaque known as "Tabula Traiana" and Trajan's Bridge, Šarkamen, Naisus along with Mediana, Justiniana Prima, Dijana Karataš, Kale Krševica, Hisar and Drenovac a cultural route has been created (The Roman Emperors Route) that leads travelers through the time when the Danube was the eastern border of the Roman Empire. In this paper, the authors discuss some issues related to presentation and interpretation of Serbian archaeological sites in tourism, emphasizing the importance of face-to-face interpretation for the experience of visitors and tourists. It should be kept in mind that archaeological sites are not visited only by (mass) tourists who are partially interested in sightseeing, but also by travelers who choose Serbia because of those attractions. In that case, it is about archaeological tourism or the so-called archaeotourism, as a specific form of cultural tourism, which requires an adequate variety of quality interpretation in situ.
\end{abstract}

Keywords:

archaeological site, tourism, presentation, interpretation, Roman heritage 